
$\mathbf{A} \mathbf{C}_{\mathrm{ASE}} \mathbf{S}_{\mathrm{TUd}}$
FOOD SCIENCE.
RESEARCH JOURNAL
ISSN-0976-1276 Visit us : www.researchjournal.co.in Volume 10 | Issue 2 | October, 2019 | 237-242 DOI : $10.15740 / \mathrm{HAS} / \mathrm{FSRJ} / 10.2 / 237-242$

\title{
Anti-diabetic property of purple rice
}

\author{
Chungkham $\mathrm{N}_{\text {ganthoibi and }} \mathrm{Namita}_{\text {Singh }}$
}

Purple rice is a colored variety of rice (Oryza sativa L.) that is cultivated widely in South-East Asia. It contains purple black pigments (anthocyanins) and is use as a food colorant in bread, ice cream and liquor. It is entirely non-allergenic and gluten free. Its purple colour is from antioxidant anthocyanins. Several health benefits are attributed to purple rice. Some of which are explained. The antioxidant activity in purple rice may also have anti-inflammatory and anti-carcinogenic properties. A powerful antioxidant, anthocyanins has been link to reduce cases of diabetes, obesity, and heart disease. The present article will collect health benefit of purple rice, beneficial effect against diabetes mellitus, dietary anthocyanins and insulin sensitivity/resistance, antidiabetic activity. In vivo and in vitro and few clinical studies data to suggest that dietary anthocyanins could ameliorate insulin resistance and offer health benefits in diabetic conditions. One of the key features of their pharmacological effects appear to be linked to multiple mechanisms ranging from inhibiting carbohydrate digestion in the gut, pancreatic $\beta$-cell protection and insulin secretion to enhancing sensitivity in vital organ.

Key Words : Anti-diabetic, Anthocyanins, Insulin resistance/sensitivity

How to cite this article : Nganthoibi, Chungkham and Singh, Namita (2019). Anti-diabetic property of purple rice. Food Sci. Res. J., 10(2): 237-242, DOI : 10.15740/HAS/FSRJ/10.2/237-242.Copyright@ 2019: Hind Agri-Horticultural Society.

\footnotetext{
Author for correspondence :

Chungkham Nganthoibi, Department of Food Science and Nutrition, College of Community Science, Central Agricultural

University, Sangsanggre, Tura (Meghalaya) India

Email: singhpapak9642@gmail.com

Associate Authors' :

Namita Singh, Department of Food Science and Nutrition, College of Community Science, Central Agricultural University, Sangsanggre, Tura (Meghalaya) India

Email: drnam2007@rediffmail.com
} 